\title{
Evaluation of mango seed kernel and pineapple peels as carbon sources for microbial protease production
}

\author{
Yaya Abubakar Gimba ${ }^{1,2 *}$, Oluwatosin Kudirat Shittu2,3, Abdulkadir Abubakar ${ }^{3}$, and Alhassan \\ Hussaini Egbako ${ }^{1}$
}

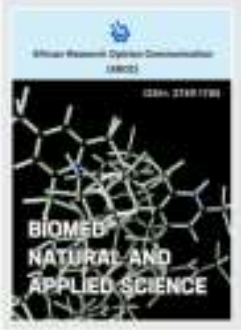

\author{
${ }^{1}$ Department of Biological Sciences, Niger State Polytechnic Zungeru, Nigeria \\ ${ }^{2}$ Biochemistry Department, School of Life Sciences, Federal University of Technology, \\ P.M.B 65, Minna, Niger State, Nigeria \\ ${ }^{3}$ Nanotechnology research Group, Centre for Genetic Engineering and Biotechnology, \\ Federal University of Technology, P.M.B 65, Minna, Niger State, Nigeria
}

Correspondence should be addressed to G.A.Y. E-mail gimbayaya@gmail.com

Proteolytic enzymes are ubiquitous in occurrence and find multiple applications in various industrial sectors. Although there are many microbial sources available for producing proteases, only a few are recognized as commercial producers. Utilization and recycling of renewable resources that pose threat to the environment can be systematically carried out to bring about resource productivity needed to make human activity sustainable. In the present study, we evaluated the phytochemical, antimicrobial, and protease production ability of mango seed kernel and pineapple peels. The proximate compositions and antimicrobial analysis of Mango seed kernel and pineapple peels were evaluated using standard protocols. We evaluated the protease production of Bacillus megaterium using the mango seed kernel and pineapple peels as the carbon sources. Our results revealed that mango seed kernel has low moisture, ash and crude fibre content but has high oil and crude protein content while pineapple peels have high moisture and fibre content but low in ash, crude protein and oil content. Mango seed extract also demonstrated antimicrobial activities against $B$. subtilis, less sensitive to $B$. megaterium and no activity against $A$. niger. However, the pineapple peel extracted is highly sensitive to $B$. subtilis and $S$ aureus but demonstrated no activity against $P$. aeroginosa and $A$ niger. The $B$. megaterium exhibited higher protease production ability when mango seed kernel was used as a carbon source at all tested concentrations. In conclusion, the information obtained from proximate and antimicrobial analysis of mango seed kernel and pineapple peels serves as a guide for the possible utilization as carbon sources for microbial enzyme production. Thus, both pineapple peel and mango seed kernel can be bioremediated when used as carbon sources for protease production.

Keywords: Phytochemical; antimicrobial; protease: mango seed kernel: pineapple peels

Citation: Gimba, Y.A., Shittu, O.K., Abubakar, A., and Egbako, A.H. (2021). Evaluation of mango seed kernel and pineapple peels as carbon sources for microbial protease production. BIOMED Natural and Applied Science,1(3):15-23, https://doi.org/10.53858/bnas01031523

Received: 22 August 2021, Revised: 09 October 2021, Published: 10 December 2021

\subsection{Introductions}

Proteases (EC 3.4) also referred as peptidases or proteinases are the hydrolase enzymes which have small size, compact molecules, spherical structures and are capable of hydrolyzing peptide bonds in the primary structure of proteins and peptids [1]. They are used to cleave the proteins specifically to produce useful peptides in the processes [2].

Proteases are one of the most important group of industrial enzymes and account for nearly $60 \%$ of the total enzyme sale [3]. They are generally used in detergents, food industries, leather, meat processing, cheese making, silver recovery from photographic film, production 
of digestive and certain medical treatments of inflammation and virulent wounds [4]. They also have medical and pharmaceutical applications.

Proteolytic enzymes are ubiquitous in occurrence, being found in all living organisms, and are essential for cell growth and differentiation. The extracellular proteases are of commercial value and find multiple applications in various industrial sectors. Although there are many microbial sources available for producing proteases, only a few are recognized as commercial producers [5]. Of these, strains, Bacillus species dominate the industrial sector [6]

Bacillus megaterium is an important family of gram positive bacteria, members of this family comprise substantial proportion of the micro flora of free living saprophytes in soil, fresh water, marine environments and many other natural habitats [7]. Primarily a soil bacterium, $B$. megaterium is also found in diverse environments from rice paddies to dried food, seawater, sediments, fish, normal flora, and even in bee honey [8]. Taxonomically, $B$. megaterium is placed into the $B$. subtilis group of Bacilli although there is only a small degree of relation in the genome structure between $B$. megaterium and $B$. subtilis. $B$. megaterium is able to grow on a wide variety of carbon sources and has, thus, been found in many ecological niches, such as waste from meat industry or petrochemical effluents [8].

Utilization and recycling of renewable resources that pose threat to the environment can be systematically carried out to bring about resource productivity needed to make human activity sustainable [9]. Nigeria is an agro based country that produces large quantities of agro industrial residues which are rich in nutrients like carbon, nitrogen, minerals, and biomass residues [10]. These agricultural wastes can be used as substrate for enzyme production owing to economic feasibility, as it can help in solving pollution problems which may be caused by their disposal $[11,12]$ The aim of this research is to produce and characterize protease by Bacillus magaterium using mango seed kernel and pineapple peel as carbon source

\subsection{Materials and Methods}

\subsection{Reagents}

Nutrient agar, glycerol, glucose, peptone, casein, anhydrose magnesium sulphate, potassium hydrogen phosphate, anhydrose iron sulphate, glyceline sodium hydroxide buffer, trichloroacetic acid, alkaline copper reagent, folins reagent, Bradford reagent, citrate buffer, phosphate buffer, tris- $\mathrm{HCl}$ buffer,

\subsection{Microbial Culture}

The culture of Bacillus megaterium used was obtained from Center for Genetic Engineering of Federal University of Technology Minna. Stock cultures were maintained in nutrient broth medium with $70 \%$ glycerol, cultures were preserved in a refrigerator. A loopful of bacterial strain (Bacillus megaterium) were transferred to a tube of sterile nutrient broth and allowed to grow overnight at $37^{\circ} \mathrm{C}$ before being used for inoculation.

\subsection{Collections of mango seed and pineapple peels}

Fresh mango was bought from Minna fruit market by March 2016, the seeds were broken and the content were sun dried, ground to fine mesh size and stored in plastic jars. Fresh pineapple peels were collected from fruit vendors at peeling points from Minna fruit market. The peels were washed with tap water to remove debris after which they were blended. 


\subsection{Proximate Analysis of Mango Seed and Pineapple Peels}

The proximate compositions including; crude proteins, crude fibre, moisture content, ash content, crude fat and carbohydrate contents of both mango seed kernel and pineapple peels were determined using standard procedures described in previous studies [13-15].

\subsection{Antibacterial Activity of Mango Seed and Pineapple Peel Extract}

The substrates were subjected to antimicrobial evaluation against five organism including $B$. megaterium, B. subtilis, Pseudomonas aeroginosa, Staphylococcus aureus, Aspergillus niger and as described previously [16-19]. Nutrient Agar was prepared in conical flask in accordance to the directions provided by the manufacturer. The media along with petri dishes, pipette and metallic borer were sterilized in autoclave for 15 minutes at $121^{\circ} \mathrm{C}$ and 15 psi pressure. The media was poured into petri dishes under aseptic condition. The stock solutions of corresponding extracts were prepared in distilled water. Bacterial strains were innoculated on the solidified agar media, $7 \mathrm{~mm}$ wells were punched in the agar media by using sterile metallic borer. Stock solutions of crude extract in distilled water at concentration of $20 \mathrm{mg} / \mathrm{mL}$ were prepared and $200 \mu \mathrm{l}$ from each stock solution was added into respective wells. The petri dishes were incubated at $37^{\circ} \mathrm{C}$ for 24 hours. After 24 hours antibacterial activities were measured as diameter of the zones of inhibition.

\subsection{Protease Production}

Protease enzyme production was carried out using standard media glucose, $0.5 \%(\mathrm{w} / \mathrm{v})$, peptone, $0.75 \%(\mathrm{w} / \mathrm{v})$, salt solution, $5 \%(\mathrm{v} / \mathrm{v})-\left\{\mathrm{MgSO}_{4} .7 \mathrm{H}_{2} \mathrm{O}, 0.5 \%(\mathrm{w} / \mathrm{v}), \mathrm{KH}_{2} \mathrm{PO}_{4} 0.5 \%\right.$ $(\mathrm{w} / \mathrm{v})$,$\} and \mathrm{FeSO}_{4} .7 \mathrm{H}_{2} \mathrm{O}, 0.01 \%(\mathrm{w} / \mathrm{v})$ on a shaker incubator at $160 \mathrm{rpm}\left(37^{\circ} \mathrm{C}\right)$ for 48 hours. The culture medium was harvested and was subjected to centrifugation at $10,000 \mathrm{rpm}$ for $20 \mathrm{~min}$ to obtain crude protease extract which served as enzyme source.

\subsection{Determination of Enzyme Activity}

Protease activity of the crude extract was determined by the protease activity method using L-Tyrosine $(0-1000 \mathrm{mg} / \mathrm{L})$ as the standard. L-Tyrosine standards were prepared in different concentrations and the standard calibration curve was obtained. Total protein activity was calculated from standard calibration curve. Protease activity of the crude extract was determined according the following steps. $100 \mu \mathrm{l} 0.5 \%$ (w/v) casein in $50 \mu \mathrm{M}$ Glycine $\mathrm{NaOH}$ buffer $\mathrm{pH} 10.0$ was added to $100 \mu$ enzyme solution and the assay mixture was incubated for 10 minutes at $55^{\circ} \mathrm{C}$ in the water bath. $3 \mathrm{ml} 10 \%$ TCA in deionized water was added to enzymesubstrate solution to terminate the reaction, the mixture was centrifuge for 15 at 10,000rpm. $1 \mathrm{ml}$ of filtrate was mixed with $5 \mathrm{ml}$ of alkaline copper reagent and after $15 \mathrm{~min}, 0.5 \mathrm{ml}$ of Folinciocalteu's reagent was added, up on standing for 30min. The absorbance was read at 700nm. Similarly, blank was carried out by replacing enzyme with distilled water. One unit of enzyme activity is defined as the amount of enzyme that releases $1 \mu \mathrm{g}$ of tyrosine per $\mathrm{ml}$ per minute under the same assay conditions [20-21]

\subsection{Effect of different carbon sources on protease production}

We evaluated the effect of different carbon sources on protease production Glucose was replaced with mango seed and pineapple peels juice at various concentrations of $0.5 \mathrm{~g}, 1.0 \mathrm{~g}$, $1.5 \mathrm{~g}, 2.5 \mathrm{~g}, 7.5 \mathrm{~g}$ and $10.0 \mathrm{~g}$ respectively. 


\subsection{Statistical Analysis}

In all experiments, the measurements were carried out with triplicate parallel cultures. The values reported are means \pm S.D. The results were analyzed by analysis of variance using statistical software IMB SPSS Statistics 22.

\subsection{Results}

\subsection{Proximate composition of mango seed kernel and pineapple peels}

Mango seed kernel has low moisture, ash and crude fibre content but has high oil and crude protein content. Pineapple peels has high moisture and fibre content but low in ash, crude protein and oil content (Table 1).

Table 1: Proximate composition of Mango seed kernel and pineapple peels.

\begin{tabular}{|l|l|l|}
\hline Moisture & Mango seed (\%) & Pineapple peel (\%) \\
\hline Ash & $1.30 \pm 0.32$ & $40.97 \pm 0.83$ \\
\hline Crude protein & $7.65 \pm 0.11$ & $4.40 \pm 0.15$ \\
\hline Crude fibre & $0.60 \pm 0.28$ & $39.35 \pm 0.32$ \\
\hline Oil extract & $14.6 \pm 0.21$ & $2.30 \pm 1.23$ \\
\hline Carbohydrate & $69.98 \pm 1.01$ & $10.83 \pm 0.43$ \\
\hline
\end{tabular}

Values are mean \pm standard deviation of three (3) independent variables

\subsection{Anti-Microbial Activity of Mango Seed Kernel Extract}

Mango seed kernel extract was tested against some industrial based microbes. The result shows that mango seed extract is sensitive against $B$. subtilis, less sensitive to $B$. megaterium and no activity against $A$. niger (Table 2 ).

Table 2: Anti-Microbial Activity of Mango Seed Kernel Extract

\begin{tabular}{|l|l|l|l|l|l|l|}
\hline \multicolumn{7}{c|}{ Concentrations $(\mathbf{m g} / \mathbf{m L})$} \\
\hline Organism & 0.04 & 0.08 & 0.12 & 0.16 & 0.20 \\
\hline \multicolumn{7}{|c|}{ Zone of inhibition $(\mathrm{mm})$} \\
\hline B. subtilis & 11.0 & 16.0 & 17.0 & 17.0 & 17.0 \\
\hline B.megaterium & - & 7.0 & 10.0 & 13.0 & 9.0 \\
\hline P. aeruginosa & 14.0 & 11.0 & 12.0 & 9.0 & 22.0 \\
\hline S. aureus & 17.0 & 14.0 & 15.0 & 18.0 & 21.0 \\
\hline A. niger & - & - & - & - & - \\
\hline
\end{tabular}

Key: B- Bacillus, P- Pseudomonas, S- Staphylococcus, A- Aspergillus

\subsection{Anti-Microbial Activity of Pineapple Peel Extract}

Pineapple peel extracted was tested against some industrial base microbes. The result shows it is highly sensitive to $B$. subtilis and $S$ aureus but slightly sensitive against $B$. megaterium. It shows no activity against $P$. aeroginosa and $A$ niger (Table 3 ). 


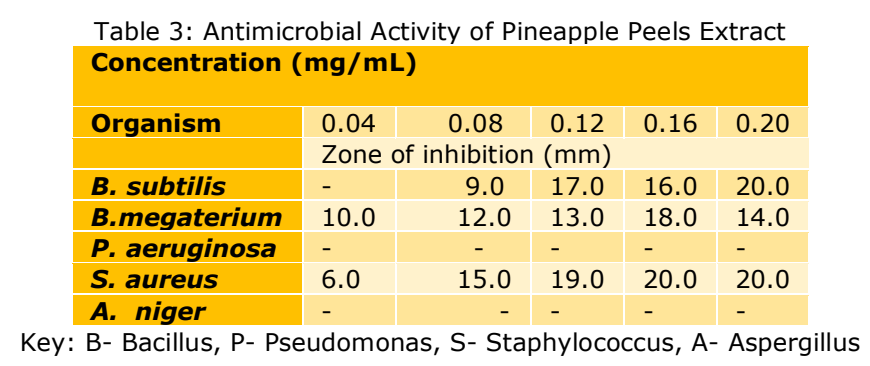

\subsection{Effects of Different Carbon Sources on Protease Production.}

The extracellular protease enzyme was synthesized by Bacillus megaterium. The results obtained in this work revealed the ability of Bacillus megaterium to produce extracellular protease. Figure 1 shows the ability of $B$. megaterium to utilize glucose, mango seed kernel and pineapple peels as a carbon source and energy material to produce protease enzyme. Interestingly, the results indicated that $B$. megaterium exhibited their maximum ability to biosynthesize protease when grown on mango seed kernel.

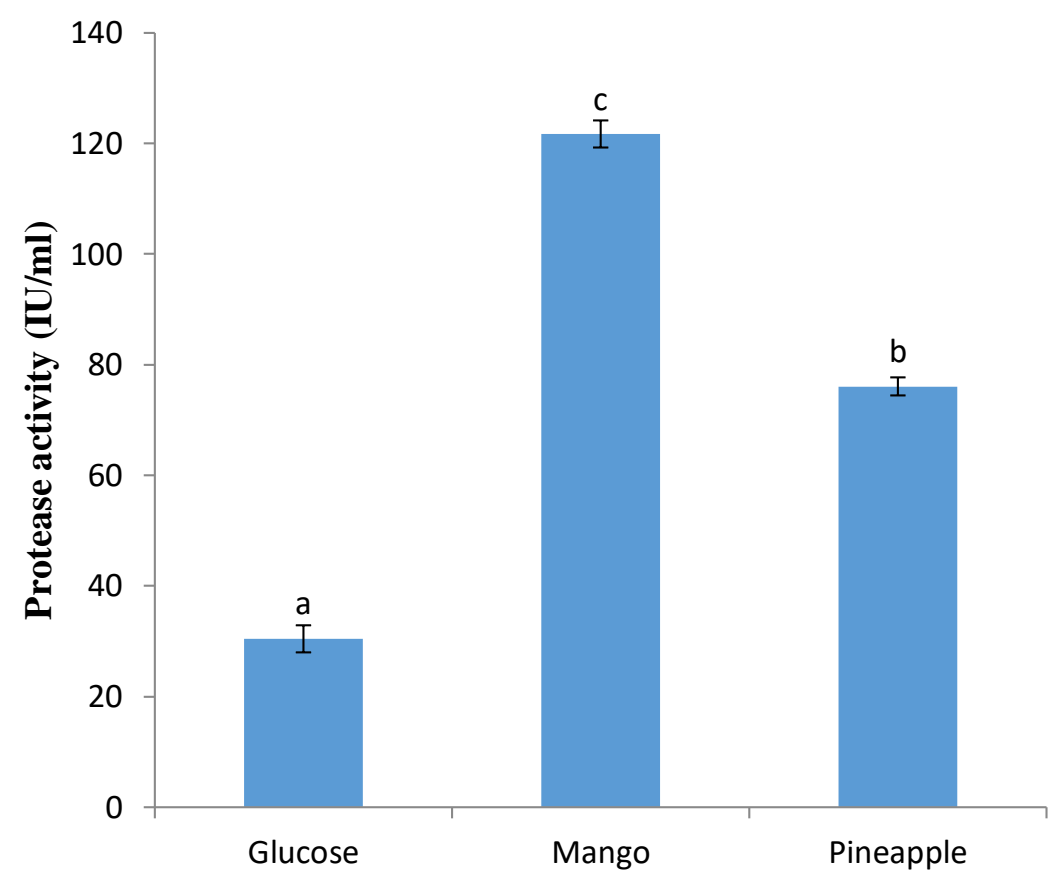

Figure 1: Effects of Different Carbon Sources on Protease Production. Results are mean of three independent determinations. Error Bars correspond to standard error of mean.

\subsection{Effect of Different Carbon Source Concentration on Protease Production.}

Different substrate (glucose, mango seed kernel and pineapple peels) concentrations were applied to investigate their effect on protease productivity by Bacillus megaterium. Figure 2 indicated that the maximum productivity was attained when mango seed kernel was used as carbon source at all tested concentrations. 


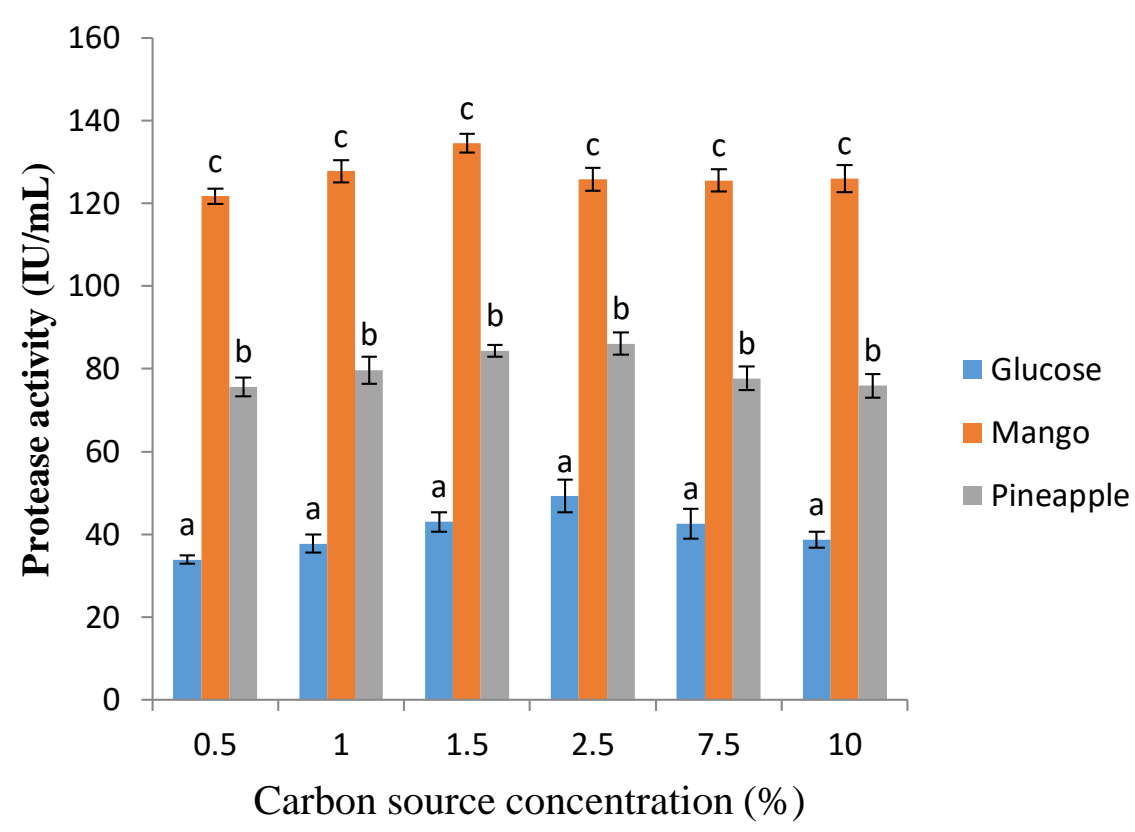

Figure 2: Effect of Different Carbon Source Concentration on Protease Production. Results are mean of three independent determinations. Error Bars correspond to standard error of mean.

\subsection{Discussion}

High carbohydrate content of both mango and pineapple peels can serve as essential carbon source for microbial growth. This high carbohydrate content can stimulate expression of many hydrolytic enzymes, protease inclusive. The amount of enzymes produced by a microorganism depends on the amount of carbon sources available and utilized by the producing organism. The protein content of both mango seed and pineapple peels can serve as essential nitrogen source for normal microbial growth and metabolism. The high protein content of this agro wastes used for enzyme production can elicit the secretion of protease enzyme in the fermentation media.

The ash contents of both mango and pineapple peels is relatively low. Low ash is usually an indication of low inorganic mineral content [22]. According to the study of Fowomola, [23], Mango seed kernel was found to be high in potassium, magnesium, phosphorus, calcium and sodium. Potassium is an essential nutrient and has an important role in the synthesis of amino acids and proteins [23]. Calcium and magnesium play a significant role in photosynthesis, carbohydrate metabolism, nucleic acids and binding agents of cell walls [24].

The moisture content of mango seed was considerably low compared to that of pineapple. The high moisture content of pineapple peels will make it suitable for submerge and solid state fermentation. The reduced moisture content in the mango seed is an indication that their shelf life would be prolonged and that deterioration due to microbial contamination would be limited [25]. The pineapple peels has higher fibre content than mango seed. The high crude of pineapple compensates for its low carbohydrate content and can also serve as carbon source for microbial growth. Most microorganisms have enzymatic mechanism to hydrolyze lignocelluloses (fibre). Mango seed is rich in fat than pineapple peels. The high fat can also serve as carbon source for microbial cultivation in the absence of carbohydrate. Mango seed 
can also serve as substrate for microbial lipase production. The fat content of mango seed can also be utilized for industrial biodiesel production.

The microbial strains used to screen the possible antimicrobial activity of mango seed pineapple extract are based on their industrial application [26]. Interpretation of inhibition zones of test culture was adopted from Johnson and Case [27]. A zone of inhibition is an area around the point in the media where the test sample is introduced and where no test organisms (pathogenic bacterial strains) are found to be growing. A diameter of zone of inhibition of 10 or less indicates the test product being resistant to the test organisms (pathogens), diameter zone of inhibition of 11 to 15 indicates the test product having an intermediate resistant to the test organisms. A diameter with a zone of inhibition of 16 or more indicates that test product is highly resistance to test organisms. Pineapple peels extract was also not active against $P$. aeroginosa but was sensitive to $B$. sutilis from concentration of $0.12 \mathrm{~g} / \mathrm{ml}$ and above. The activity of mango seed kernel extracts on $B$. megaterium was not significant but highly sensitive to $B$. subtilis. The two extract were sensitive to $S$. aureus at all concentrations tested. Mango seed extract was also active against $P$. aeroginosa at all tested concentrations. Both mango seed kernel and pineapple peel extracts did not show any activity against $A$. niger.

There are general reports showing that different carbon sources have different influences on extra cellular enzyme production by different strains [26]. The effect of the different carbon sources on growth and enzymatic production on sub-merge fermentation was studied by growing the microorganism in a medium containing different carbon sources including agriculture wastes. Most of the proteases of microbial origin are extracellular and excreted through the cell membrane into the culture medium consisting of a suitable substrate. Among all the substrates tested for protease production, mango seed holds the best capacity for protease production by $B$. megaterium (Figure 1 ), which indicates that it contains all the basic nutrients for bacterial growth and protease production. Mango seed proves to be a good protease producer because it is rich in protein contents than any other source used in the present study. Pineapple peels are mainly composed of carbohydrates with little protein contents and is a rich source of insoluble fibre.

The standardization was carried out by varying the level of substrate i.e. glucose, mango seed and pineapple peels from 0.5 to $10 \mathrm{~g}$ per $200 \mathrm{ml}$ of culture medium. Protease production in glucose enriched media was optimal at $2.5 \mathrm{~g} / 100 \mathrm{ml}$ of incubation media, mango at $1.5 \mathrm{~g} / 100 \mathrm{ml}$ of incubation media and pineapple was at $2.5 \mathrm{~g} / 100 \mathrm{ml}$ of incubation media was synthesized by $B$. megaterium. (Fig. 2). Results revealed that protease production per gram dry carbon was increased by increasing the amount of substrate. This might be due to increase in nutrient composition of culture media.

\subsection{Conclusion}

The information obtained from proximate and antimicrobial analysis of mango seed kernel and pineapple peels serves as a guide for the possible utilization as carbon source for microbial enzyme production. Thus, both pineapple peel and mango seed kernel can be bioremediated when used as carbon source for protease production.

Conflict of Interest: The author declared no conflict of interest exist

Ethical Approval: Not applicable 
Authors contributions: The work was conducted in collaboration of all authors. All authors read and approved the final version of the manuscript.

\section{References}

1. Tozser, J., Janos, A., \& Ferenc, T. (2013). Research applications of proteolytic enzymes in molecular biology (Review). Biomolecules, 3, 923-942.

2. Amara, A. A., Salem, S. R. \& Shabeb, M. S. A. (2009). The Possibility to Use Bacterial Protease and Lipase as Biodetergent. Global Journal of Biotechnology \& Biochemistry, 4(2), 104-114.

3. Saraswathy, N., \& Riddhi, S. (2014). Protease: An enzyme with multiple industrial Applications. World Journal of Pharmacy and Pharmaceutical Sciences, 3(6), 568-579.

4. Barindra, S., Debashish, G., Malay, S., \& Joydeep, M. (2006). Purification and characterization of a salt, solvent, detergent and bleach tolerant protease from a new gamma Proteobacterium isolated from the marine environment of the Sundarbans. Process Biochemistry, 41: 208-215.

5. Gupta, R., Beeg, Q. K. \& Loranz, P., (2002a). Bacterial alkaline proteases: molecular approaches and industrial applications. Applied Microbiology Biotechnology, 59(1), 15-32.

6. Gupta, R., Beeg, Q. K., Khan S. \& Chauhan, B., (2002b). An overview on fermentation, downstream processing and properties of microbial alkaline proteases. Applied Microbiology Biotechnology, 60(4), 381-395.

7. Banerjee, S., Devaraja, T.N., Shariff, M., \& Yusoff, F.M. (2007). Journal of Fish Discussion, 30(7), 383-389.

8. Vary, P. S. (1994). Prime time for Bacillus megaterium. Microbiology, 140, 1001-1013.

9. Tsado, A. N., Egwim, E.C., Oyeleke, S.B., and Shittu, O.K., (2021). Screening, production and partial characterization of proteases from microbial isolates obtained from waste dumpsites. BIOMED Natural and Applied Science,1(2):45-53, https://doi.org/10.53858/bnas01024553

10. Ibrahim, Z.M., Makut M.d., Omale, A.A., Abubakar, M.U. (2021). Evaluation of the efficacy and optimization of indigenous microbial isolate for herbicides (Paraquat Dichloride, Glyphosate, and Glyphosate isopropylamine) degradation, BIOMED Natural and Applied Science,1(2):24-30, https://doi.org/10.53858/bnas01022430

11. de Azeredo, L. A. I., Gomes, P. M., Sant'Anna,G. L., Castilho, L. R., \& Freire, D. M. G. (2007). Production and regulation of lipase activity from Penicillium restrictum in submerged and solidstate fermentations. Current Microbiology, 54, 361-365.

12. Arvanitoyannis, I. S., \& Varzakas, T. H. (2008). Vegetable waste treatment: Comparison and critical presentation of methodologies. Critical Review of Food Science Nutrition, 48, 205-247.

13. Bashir, L., Ossai, P.C., Shittu, O.K., Abubakar, A.N. and Caleb, T., 2015. Comparison of the nutritional value of egg yolk and egg albumin from domestic chicken, guinea fowl and hybrid chicken. Journal of Experimental Agriculture International, pp.310-316.

14. Tsado, A.N., Lawal, B., Santali, E.S., Shaba, A.M., Chirama, D.N., Balarabe, M.M., Jiya, A.G. and Alkali, H.A., 2015. Effect of different processing methods on nutritional composition of Bitter Leaf (Vernonia amygdalina). IOSR Journal of Pharmacy, 5(814.44).

15. Adeniyi, K.A., Olayemi, I.K., Shittu, K.O., Busari, M.B., Mohammed, S.S., Bashir, L. and Yusuf, R.S., 2016. Comparative phytochemical and antinutritional constituents of Nigeria sweet and bitter honey varieties. World Journal of Pharmaceutical Research, 5(3), pp.255-267. 
16. Lawal, B., Shittu, O.K., Oibiokpa, F.I., Mohammed, H., Umar, S.I. and Haruna, G.M., 2016. Antimicrobial evaluation, acute and sub-acute toxicity studies of Allium sativum. Journal of Acute Disease, 5(4), pp.296-301.

17. Yusuf, A.A., Lawal, B., Yusuf, M.A., Adejoke, A.O., Raji, F.H. and Wenawo, D.L., 2018. Free radical scavenging, antimicrobial activities and effect of sub-acute exposure to Nigerian Xylopia Aethiopica seed extract on liver and kidney functional indices of albino rat. Iranian journal of toxicology, 12(3), pp.51-58.

18. Yusuf, A.A., Lawal, B., Abubakar, A.N., Berinyuy, E.B., Omonije, Y.O., Umar, S.I., Shebe, M.N. and Alhaji, Y.M., 2018. In-vitro antioxidants, antimicrobial and toxicological evaluation of Nigerian Zingiber officinale. Clinical Phytoscience, 4(1), pp.1-8.

19. Umar, S.I., Lawal, B., Mohammed, B.A., Obiekezie, C.I., Adewuyi, A.H., Babalola, S.B. and Ariyeloye, S.D., 2019. Antioxidant and antimicrobial activities of naturally occurring flavonoids from $M$. heterophylla and the safety evaluation in Wistar rats. Iranian Journal of Toxicology, 13(4), pp.39-44.

20. Folin, O. and Ciocalteau, V.J. (1929). On Tyrosine and Tryptophan Determinations in Proteins. Journal of Biological Chemistry, 73:62-650.

21. Anson, M.L. (1938) The Estimation of Pepsin, Trypsin, Papain and Cathepsin with Hemoglobin. Journal of General Physiology, 22:79-89

22. Oloyede, O. I. (2005). Chemical profile of unripe pulp of carica papaya. Parkistan Journal of Nutrition, 4(6), 379-381.

23. Fowomola, M. A. (2010). Some nutrient and antinutrient contents of mango (mangniferal indica) seed. African Journal of Food science, 4(8), 472-476.

24. Scalbert, A. (1991). Antimicrobial properties of tanin. Phytochemicals, 30, 3875-3883.

25. Dashak, D. A., Dawang, M. L. \& Lucas, N. B. (2001). An assesment of the proximate analysis of local produced spices know as dadawa from three markets in Plauteu state of Nigeria. Food chemistry, 75(2), 231-235.

26. El-Safey E. M. \& Abdul-Raouf U. M. 2004. Production, purification and characterization of protease enzyme from Bacillus subtilis. Botany and Microbiology Department, Faculty of Science, Al-Azhar University.

27. Johnson, T., Case, C. (2006). Chemical Methods of Control, adapted from Laboratory Experiments in Microbiology, Brief Edition, 4th ed. Redwood City, CA: Benjamin/Cummings Publishing Co., available online from The National Health Museum, Access Excellence Activities Exchange.

Submit your article to AROC JOURNALS

-AROC in Pharmaceutical and Biotechnology

-AROC in Agriculture

-AROC in Bioinformatics

-AROC in Food and Nutrition

-AROC in Natural Product Research

-BIOMED Natural and Applied Science

Via https://arocjournal.com/

Copyright (c) 2021 Gimba et al. This is an open access article distributed under the terms and conditions of the Creative Commons Attribution License (CC BY) which allowed unrestricted download, distribution and reused as long as the original authors are properly cited. 